\title{
PENCIPTAAN NASKAH DRAMA BHRE SATYA PALASTRA
}

\author{
Vera Devitasari \\ Institut Seni Indonesia Yogyakarta
}

\begin{abstract}
Abstrak: Bhre Satya Palastra adalah drama yang diciptakan berdasar pada perbedaan tokoh Menak Jingga dari cerita rakyat Darmawulan dibandingkan dengan kondisi sosial dan politik pada masa kini. Naskah ini mengangkat kisah kematian adipati setia akibat penguasa yang lalim. Naskah Bhre Satya Palastra ini diciptakan dengan teori resepsi secara diakronik untuk mengolah data dan teori adaptasi untuk proses penyaduran. Hasil akhir dari penciptaan ini berupa sebuah naskah drama bertema kemenangan atas kematian.
\end{abstract}

Kata Kunci : Naskah drama, Bhre Satya Palastra, Menak Jingga, cerita rakyat, resepsi, diakronik

\begin{abstract}
Bhre Satya Palastra is a play inspired from many version of Menak Jingga's character from Damarwulan folklore compared to the current social and political conditions. The script tells about the death of a loyal right-hand man caused by a corrupt ruler. Bhre Satya Palastra is created by using reception theory diacronically to sort out the data and by using adaptation theory to trace the adaptations. This research results in a playscript with the theme of winning over death.
\end{abstract}

Key words : playscript, Bhre Satya Palastra, Menak Jingga, folklore, reception, diachronic

\section{Pendahuluan}

Cerita tentang Menak Jingga merupakan salah satu cerita rakyat atau folklor. Menak Jingga merupakan adipati Blambangan yang terkenal karena memberontak pada kerajaan Majapahit. Sebagai seorang adipati, Menak Jingga memiliki karakteristik fisik yang gagah dan perkasa. Menurut Babad Majapahit NB. 76, Menak Jingga merupakan adipati Blambangan yang digambarkan sebagai berikut:

Seorang adipati yang perkasa, tidak mempan senjata dan berbagai macam logam. Sangat gagah dan sakti. Hanya satu kekurangannya yaitu wajahnya jelek dan tidak pantas untuk digambarkan. Tetapi yang menjadi kelebihannya yaitu dia sangat ditakuti oleh musuh di kanan kirinya (Irawan, 2013).

Sedangkan menurut Purwadi, ketua Asosiasi Masyarakat Adat Using, yang dikutip dari jurnal ilmu humaniora dengan judul Janger Banyuwangi Dan Menakjinggo: Revitalisasi Budaya oleh Novi Anoegrajekti (2014), menyatakan bahwa Menak Jingga adalah seorang ksatria, tinggi besar, gagah berani, dan merupakan tokoh yang menjadi ikon dalam cerita itu dan sekaligus sebagai pahlawan Blambangan/Banyuwangi.

Sosok Menak Jingga kemudian menjadi kontroversi karena memiliki versi yang saling bertolak belakang. Hal ini diperkuat dengan pernyataan Hirwan Kuardhani berikut ini:

Tokoh Menak Jingga merupakan tokoh kontroversi, di satu pihak ia merupakan 
tokoh antagonis dari Damarwulan, sebaliknya Menak Jingga merupakan tokoh hero bagi masyarakat Blambangan, sesungguhnya siapakah tokoh tersebut sangat menarik untuk ditelusuri dan dicermati (Kuardhani, 2000).

Bagi masyarakat luas, Menak Jingga dianggap sebagai seorang adipati yang buruk rupa, pincang, bengis, kejam dan perongrong kekuasaan Majapahit. Penggambaran sosok Menak Jingga tersebut lebih dikenal dengan sebutan versi Mataram. Sedangkan menurut masyarakat Banyuwangi (Blambangan) atau versi Banyuwangi, Menak Jingga merupakan adipati yang bijaksana, gagah, dan tampan. Sehingga pantas dijadikan sebagai sosok pahlawan. Menurut Novi, Menak Jingga merupakan tokoh sentral dalam sejarah Blambangan yang ditempatkan sebagai seorang ksatria, pemimpin, pahlawan, dan tokoh kebanggaan masyarakat Using (Anoegrajekti, 2014).

Perbedaan pada penggambaran tokoh Menak Jingga sangat menarik untuk ditelusuri lebih mendalam. Apakah penggambaran tokoh Menak Jingga merupakan sebuah strategi politik untuk menjatuhkan mental rakyat bawahan darinegara penguasa. Sehingga muncul kecurigaan bahwa cerita rakyat Menak Jingga telah dikontruksi menjadi sedemikian rupa. Terutama perihal penokohan Menak Jingga yang memunculkan stigma negatif.

Berkembangnya stigma negatif terhadap tokoh Menak Jingga menyudutkan masyarakat Banyuwangi (Nurullita, 2015). Masyarakat Banyuwangi dianggap memiliki sifat dan perwatakan yang sama dengan Menak Jingga. Yakni, ucapannya kasar, tidak memiliki kewibawaan, dan berperilaku buruk. Akan tetapi pada saat yang sama ada pembacaan yang berbeda dari masyarakat Banyuwangi.

Meski memiliki versi cerita yang saling bertolak belakang, namun cerita rakyat Damarwulan - Menak Jingga dapat menjadi media pendidikan. Karena cerita rakyat Damarwulan - Menak Jingga mengungkap sifat alamiah manusia yang selalu haus akan kekuasaan, yang kuat selalu mengalahkan yang lemah dan yang baik mengalahkan yang buruk.

Berangkat dari gagasan diatas, perbedaan interpretasi tokoh Menak Jingga pada versi cerita rakyat Damarwulan Menak Jingga menginspirasi penciptaan naskah drama dengan judul Bhre Satya Palastra. Naskah drama Bhre Satya Palastra akan dikembangkan menjadi naskah drama tentang Menak Jingga versi baru. Dengan menghadirkan pihak ketiga pada pertarungan Damarwulan dan Menak Jingga sebagai tokoh utama dalam cerita

Bersumber dari perbedaan versi tokoh Menak Jingga pada cerita rakyat Damarwulan - Menak Jingga maka ditarik rumusan penciptaan sebagai berikut:

1. Bagaimana proses penciptaan naskah drama Bhre Satya Palastra yang diresepsi dari perbedaan versi tokoh Menak Jingga pada cerita rakyat Damarwulan - Menak Jingga?

2. Bagaimana menciptakan naskah drama Bhre Satya Palastra yang dapat menggambarkan kondisi sosial politik saat ini?

Naskah drama Bhre Satya Palastra ini mempunyai beberapa tujuan untuk penciptaannya. Diantaranya ialah :

1. Untuk menciptakan naskah drama Bhre Satya Palastra yang terinspirasi dari perbedaan versi tokoh Menak Jingga pada cerita rakyat Damarwulan - Menak Jingga.

2. Untuk menciptakan naskah drama Bhre Satya Palastra yang dapat menggambarkan kondisi sosial politik saat ini.

3. Untuk melestarikan cerita rakyat Damarwulan - Menak Jingga di tengah era millenial dengan cara menjadikannya sebagai ide penciptaan naskah drama. 
1.2.4. Untuk menambah kekayaan naskah drama yang terinspirasi dari tokoh Menak Jingga pada cerita rakyat Damarwulan Menak Jingga

\section{Penelitian Sebelumnya}

Dari ketujuh karya sastra yang berdasarkan cerita rakyat Damarwulan Menak Jingga, yaitu: (1) Serat Damarwulan ditulis oleh R.Ng. Selawinata pada tahun 1885 (Supadma, 2011). (2) Babad Majapahit NB. 76 koleksi Perpustakaan Nasional RI. (3) Layang Damarwulan suntingan Van Hinloppen Labberton pada tahun (Kuardhani, 2000) (4) Ringkasan versi Kethoprak dikutip (Kuardhani, 2000). (5) Sandhyakala Ning Majapahit karya Sanusi Pane (2013) (6) Novel Menak Jingga Sekar Kedaton karya Langit Kresna Hariadi (2013).

\section{Teori Penciptaan}

Secara definitif, menurut Nyoman Kutha Ratna, resepsi sastra berasal dari kata recipere (Latin), reception (Inggris), yang diartikan sebagai penerimaan atau penyambutan pembaca (2015). Pembaca menjadi faktor penting dalam berdirinya sebuah karya sastra. Hal ini diperkuat pendapat Jausz bahwa pembaca yang menilai, menikmati, menafsirkan, memahami karya sastra menentukan nasibnya dan peranannya dari segi sejarah dan estetik (Teeuw, 2015).

A Teeuw dalam bukunya yang berjudul Sastra Dan Ilmu Sastra (2015), menjelaskan bahwa ada tiga bentuk resepsi yang khas yakni: penyalinan, penyaduran dan penterjemahan. Penyalinan yang dimaksud di sini ialah penyalinan naskah, tulisan tangan, yang diteliti oleh filologi, tepatnya: tekstologi. Penyaduran adalah proses sebuah teks digarap oleh seorang penulis yang kemudian, dengan menyesuaikannya dengan norma-norma baru, dengan perubahan yang membuktikan pergeseran horison harapan pembawa, dengan penyesuaian dengan jenis-jenis sastra baru, dengan pencocokan dengan tahap bahasa yang baru, dan lain-lain. Terjemahan-terjemahan karya sastra dalam bahasa lain, sama dengan sadurannya, dapat dipandang sebagai bentuk resepsi yang sekaligus dapat diartikan sebagai kreasi, dan dalam sejarah sastra di mana-mana terjemahan memainkan peranan yang sangat penting, sebagai inovasi, dan merupakan tahap esensial dalam penerimaaan norma-norma baru.

Bagi Jausz, nilai sebuah karya terletak terutama pada bagaimana karya itu dipersepsi dalam rentang waktu yang menyejarah, artinya bagaimana ia dipersepsi oleh orang pada zamannya dahulu, sekaligus oleh yang hidup saat ini. Pandangan ini dilandasi konsep Gadamer tentang 'peleburan horizon' (Fusion of Horizon) yakni bahwa dalam memahami suatu teks selalu terjadi peleburan antara pemahaman masa lalu yang dikandung teks itu dengan kepentingan pembaca saat ini (Ratna, 2015). Resepsi secara sinkronik merupakan penelitian karya sastra dalam hubungannya dengan pembaca sezaman. Sedangkan resepsi secara diakronik lebih rumit karena melibatkan tanggapan pembaca sepanjang sejarah.

Sebelum melakukan penyaduran, untuk memperoleh tanggapan pembaca mengenai perbedaan versi tokoh Menak Jingga sepanjang sejarah. Maka, dilakukan proses resepsi secara diakronik.

\section{Metode}

Jabrohim mengatakan bahwa aspekaspek sebuah naskah drama antara lain: penciptaan latar, penciptaan tokoh yang hidup, penciptaan konflik-konflik, penulisan adegan dan secara keseluruhan disusun ke dalam sebuah scenario (2009). Jika dijabarkan sebagai berikut:
1. Penciptaan Latar 
Istilah latar (setting) dalam arti yang lengkap meliputi aspek ruang dan waktu terjadinya peristiwa (Satoto, 1993). Latar ruang merupakan aspek yang menggambarkan tempat terjadinya peristiwa dalam naskah. Latar waktu merupakan aspek yang menunjukkan kapan atau waktu terjadinya peristiwa dalam naskah. Sedangkan latar suasana merupakan aspek suasana yang membangun peristiwa dalam naskah.

2. Penciptaan Tokoh

Informasi-informasi yang harus tergambar dari tokoh yakni: nama, usia, jenis kelamin, keadaan tubuhnya, ciri khas wajah, status sosial, hubungan tokoh dengan tokoh yang lainnya, dan juga karakter/sifat. Jika para tokoh sudah teridentifikasi secara tiga dimensional maka akan melahirkan tokoh yang dapat berkata (dialog) dan berlaku (action) secara wajar dalam sebuah penceritaan drama (Iswantara, 2016). Menurut Gorys Keraf dalam bukunya yang berjudul Argumentasi dan Narasi, gambaran mengenai karakter dapat juga dicapai melalui tokoh atau karakter lain yang berinteraksi dalam pengisahan (2010).

\section{Penciptaan Konflik}

Konflik yang melibatkan manusia, dan dengan demikian menjadi faktor utama pertimbangan untuk mengangkat permasalahan itu dalam sebuah narasi, dapat dibagi atas tiga macam, yaitu: konflik berupa pertarungan melawan alam, konflik berupa pertarungan antar manusia dengan manusia, dan konflik dalam diri seseorang atau konflik batin (Keraf, 2010).

\section{Penciptaan Adegan}

Adegan-adegan yang akan diciptakan pada mulanya disusun dalam treatment. Adegan merupakan bagian dari keutuhan naskah yang memuat latar, tokoh, dialog dan juga petunjuk laku. Adegan diciptakan saling berhubungan satu sama lain sehingga menjadi sebuah rangkaian utuh yang disebut sebagai naskah drama.

5. Secara Keseluruhan Disusun Ke Dalam Sebuah Skenario

Jabrohim membagi proses tersebut ke dalam dua tahap berikut:

a. Penempatan elemen bersama-sama ke dalam skenario dasar (kasar) berupa outline naratif yang mengisahkan cerita (story) drama itu.

b. Menulis adegan itu sendiri lengkap dengan dialog dan petunjuk panggung (stage direction) (2009).

\section{Tinjauan Cerita Rakyat Menak Jingga dalam Diakronik}

Pada Menak Jingga Nagih Janji memiliki penggambaran sosok Menak Jingga sebagai ksatria dan pahlawan. Hal ini terjadi karena lakon Menak Jingga Nagih Janji menjadi representasi kepercayaan masyarakat Banyuwangi. Masyarakat Banyuwangi memiliki pandangan bahwa Menak Jingga merupakan tokoh protagonis yang gagah, tampan, sakti mandraguna dan layak untuk dijadikan pahlawan.

Pada versi novel Menak Jingga Sekar Kedaton (Hariadi, 2013) sangat berani menghadirkan sosok Menak Jingga atau Bhre Wirabumi yang berbeda dengan versi Mataram. Bahkan Langit Kresna Hariadi menunjukkan bahwa tokoh antagonisnya bukanlah Menak Jingga seperti yang selama ini ada di cerita rakyat Damarwulan Menak Jingga (2013). Sedangkan pada versi babad, serat ataupun layang, secara garis besar menggambarkan Menak Jingga sebagai sosok yang mengerikan. Penuh amarah dan kejam. Buruk rupa serta merugikan banyak orang, baik kerajaan Majapahit ataupun rakyat Blambangan.

Penciptaan ketujuh karya sastra di atas dapat dilihat keberpihakan penulis. Dari segi penggambaran sosok Menak Jingga utamanya. Pada versi Kethoprak dan Janger misalnya. Kedua seni pertunjukan ini sama- 
sama memiliki lakon tentang cerita rakyat Damarwulan - Menak Jingga. Akan tetapi memiliki penggambaran sosok Menak Jingga yang bertolak belakang. Jika dilihat dari segi isi cerita kedua versi ini tidak memiliki perbedaan yang signifikan, namun perbedaan penggambaran sosok Menak Jingga sangatlah mencolok.

Seni pertunjukan dapat menunjukkan budaya dan pandangan masyarakat dimana ia berada. Penulis karya sastra menjadi pembaca kebudayaan yang ada pada zamannya. Versi-versi yang ada tidak dapat divonis mana yang benar dan yang salah. Karena interpretasi penulis karya sastra sebagai pembaca kebudayaan dan sosial berbeda satu sama lainnya.

\section{Proses Penyaduran Isi Cerita}

\section{Sumber Cerita}

Menceritakan tentang Kencana Wungu yang memerintahkan Damarwulan untuk menumpas pemberontakan yang dilakukan oleh Menak Jingga. Namun karena Menak Jingga memiliki kekuatan yang luar biasa mengakibatkan Damarwulan sulit untuk mengalahkan Menak Jingga. Damarwulan kemudian merayu kedua istri Menak Jingga untuk mengetahui kelemahan Menak Jingga. Wahita dan Puyengan yang terlanjur jatuh hati pada paras tampan Damarwulan akhirnya memberitahukan kelemahan Menak Jingga. Yakni, dengan menggunakan Gada Wesi Kuning untuk membunuh Menak Jingga. Gada Wesi Kuning merupakan pusaka milik Menak Jingga. Karena perselingkuhan kedua istri Menak Jingga tersebut, Damarwulan dapat mencuri Gada Wesi Kuning dan mengalahkan Menak Jingga. Lalu menyerahkan kepala Menak Jingga pada Kencana Wungu. Pada akhir cerita, Damarwulan menjadi raja Majapahit dan menikahi Kencana Wungu, Anjasmara, Wahita dan Puyengan.

2. Proses
Berdasarkan pada analisis yang telah dilakukan, maka isi cerita mengalami penyaduran dari yang ada. Penyaduran dilakukan supaya menghadirkan cerita bahwa Menak Jingga tidak pernah melakukan pemberontakan. Menak Jingga hanyalah tokoh yang menjadi korban dari nafsu manusia untuk memperoleh kekuasaan.

3. Hasil

Naskah drama Bhre Satya Palastra bercerita tentang seorang adipati bernama Bhre Satya yang dianggap memberontak pada kerajaan Brang Kulon. Bhre Satya kemudian terbunuh oleh pusakanya sendiri yang telah dicuri oleh Candra Laleyan yang bersekongkol dengan Bala Rodra. Setelah kematian Bhre Satya ini, Widuraberjuang untuk mengungkap kematian Bhre Satya. Usaha Widura berbuah manis melalui bantuan dari Parusya. Widura laluberhasil mengungkap bahwa Bhre Satyatidak pernah berniat untuk memberontak, semua isu yang telah menyebar merupakan siasat licik $\mathrm{Ki}$ Ageng Candhala untuk menjadi penguasa di kerajaan Brang Kulon. Widura kemudian mengungkapkan kebenaran pada Ratu Ayu Lembayung tepat sebelum Bala Rodra dinobatkan sebagai adipati Brang Wetan. Ratu Ayu Lembayung lalu mengangkat Widura sebagai adipati Brang Wetan, namun ditolak oleh Widura. Widura memilih untuk kembali ke desa sebagai petani legen.

4. Judul

Pada naskah drama yang akan diciptakan tidak akan menekankan pada peristiwa kepahlawanan itu. Melainkan lebih pada peristiwa kematian yang menyebabkan terjadinya konflik. Dengan memperhatikan hal tersebut, maka naskah drama yang akan diciptakan ini diberi judul Bhre Satya Palastra. Bhre Satya merupakan nama tokoh utama. Palastra memiliki arti kematian. Jadi, Bhre Satya Palastra berarti kematian Bhre Satya. 


\section{Tema}

Tema, secara umum, dapat disebut sebagai gagasan sentral, dasar cerita yang juga mencangkup permasalahan dalam cerita, yaitu sesuatu yang akan diungkapkan untuk memberikan arah dan tujuan cerita dalam karya sastra, termasuk di dalamnya adalah teks drama (Dewojati, 2012). Naskah drama Bhre Satya Palastra mempunyai tema kekuasaan, cinta, dan pengkhianatan bernilai sama, yaitu keburukan karena dilakukan hanya untuk memuaskan nafsu semata.

\section{Premis}

Premis ialah rumusan intisari cerita sebagai landasan ideal dalam menentukan arah tujuan cerita. Ditinjau dari pelaksanaan merupakan landasan pola bangunan lakon (Harymawan, 1986). Ketika kekuasaan, cinta, dan pengkhianatan bernilai sama merupakan kalimat yang digunakan sebagai premis naskah drama Bhre Satya Palastra. Ketika naluri alamiah manusia yang tidak pernah merasa puas terus dituruti, maka segala sesuatu yang ada jadi bernilai sama.

Kekuasaan yang menjadi simbol sebuah kekuatan, cinta yang mewakili kedamaian, dan pengkhianatan yang berarti sebuah kejahatan serta merta memiliki arti yang sama. Yaitu sebuah ambisi yang berujung keburukan. Sehingga kematian bukan menjadi akhir yang menyedihkan. Melainkan menjadi sebuah kemenangan.

\section{Alur}

Naskah drama Bhre Satya Palastra mempunyai rancangan alur atau plot yang mengacu pada pola plot dramatik Aristoteles. Aristoteles membagi dramatik pada plot menjadi empat bagian, yaitu protasis (exposition), epitasio (complication), catarsis (climax), dan catastrophe (denouement). Harymawan dalam bukunya yang berjudul Dramaturgi menjelaskan bahwa protasis (exposition) merupakan bagian permulaan, dimana pada bagian tersebut dijelaskan peran dan motif lakon. Epitasio (complication) merupakan jalinan kejadian. Catarsis (climax) merupakan bagian yang menjadi puncak laku, peristiwa mencapai titik kulminasinya; sejak $1-2-3$ terdapat laku sedang memuncak (rising action). Dan catastrophe (denouement) merupakan bagian akhir atau bagian penutupan (Harymawan, 1986).

Bagian protasis atau exposition (eksposisi) terletak pada adegan 1, adegan 2, dan adegan 3. Ketiga adegan inilah yang akan menjelaskan dan mengenalkan peran serta motif para tokoh, sehingga dapat menjadi penyebab peristiwa pada bagian selanjutnya.

Bagian epitasio atau complication (komplikasi) terdapat dalam adegan 4, adegan 5 , adegan 6 , adegan 7 , adegan 8 , dan adegan 9. Konflik mulai bermunculan setelah Candra Laleyan menyamar sebagai prajurit Brang Wetan untuk melakukan siasat liciknya sampai pada adegan ketika Widura berhasil menemukan bukti bahwa Bhre Satya tidak bersalah.

Bagian catarsis atau climax (klimaks) terdapat dalam adegan 10. Ketika Widura menungkap kebenaran yang terjadi. Bahwa Bhre Satya tidak pernah memberontak pada kerajaan Brang Kulon dihadapan Ratu Ayu Lembayung.

Bagian catastrophe atau denouement (konklusi) ini akan menggambarkan bagaimana peristiwa kemenangan tanpa dihiasi oleh nafsu kekuasaan. Widura berhasil membersihkan nama Bhre Satya dari segala macam tuduhan. Sehingga Ratu Ayu Lembayung memerintahkan Widura untuk menjadi adipati Brang Wetan. Namun pada akhir cerita Widura menolak dan memilih kembali ke desa untuk menjadi petani legen.

8. Penciptaan Latar atau Ruang

Nama latar tempat mengalami penyaduran dari nama latar tempat pada cerita rakyat Damarwulan - Menak Jingga. Dalam Cerita Rakyat Damarwulan - Menak 
Jingga Kerajaan Majapahit. Pada cerita rakyat Damarwulan - Menak Jingga kerajaan Majapahit merupakan kerajaan yang memiliki daerah kekuasaan yang luas, termasuk di dalamnya adalah kadipaten Blambangan. Kerajaan Majapahit pada cerita rakyat Damarwulan - Menak Jingga dipimpin seorang ratu bernama Kencana Wungu. Sementara dalam naskah drama Bhre Satya Palastra, menjadi Kerajaan Brang Kulon. Penciptaan nama Brang Kulon terinspirasi dari letak geografis Majapahit, yaitu berada di sebelah barat Jawa Timur. Brang berasal dari kata sebrang yang berarti bagian. Sedangkan Kulon berasal dari Bahasa Jawa yang berarti Barat. Kerajaan Brang Kulon menjadi simbol latar tempat yang memiliki arti kerajaan yang berada di sebelah barat. Nama Brang Kulon mewakili penggambaran kerajaan Majapahit.

Pada cerita rakyat Damarwulan Menak Jingga kadipaten Blambangan merupakan sebuah wilayah yang diberikan kepada Menak Jingga sebagai hadiah atas kemenangannya melawan Kebo Marcuet. Dalam Bhre Satya Palastra, Kadipaten Brang Wetan merupakan nama yang diciptakan untuk mewakili wilayah kadipaten Blambangan. Blambangan yang terletak di sebelah timur di Jawa Timur menginspirasi penciptaan nama Brang Wetan. Brang berasal dari kata sebrang yang berarti bagian dan wetan memiliki arti timur.

Secara keseluruhan, naskah drama Bhre Satya Palastra ini menggunakan wilayah di kadipaten Brang Wetan sebagai latar tempat atau ruang, yaitu:

a. Istana kadipaten Brang Wetan

Istana kadipaten Brang Wetan ini terletak di pusat kadipaten Brang Wetan. Pada istana ini memiliki beberapa bagian bangunan berdasarkan fungsinya, yaitu istana pusat sebagai tempat khusus untuk adipati Brang Wetan; istana permaisuri merupakan tempat tinggal permaisuri;
Rambat Bale merupakan pendapa kadipaten Brang Wetan biasa digunakan untuk tempat rapat dan pertemuan petinggi kadipaten Brang Wetan; Taman Tirta merupakan taman yang memiliki pura disalah satu sudutnya yang ada di kadipaten Brang Wetan; dan Alun-alun merupakan sebuah tanah lapang yang sangat besar, letaknya berada di depan istana kadipaten Brang Wetan.

b. Teluk Pang-pang

Latar tempat teluk Pang-pang merupakan sebuah teluk yang berada di bagian selatan kadipaten Brang Wetan. Pemberian nama teluk Pang-pang ini berdasarkan pada nama wilayah yang dahulu pernah ada di Banyuwangi. Kini daerah tersebut memiliki nama Muncar. Teluk Pang-pang juga dijadikan sebagai tempat ibadah karena dianggap sakral dan bermanfaat bagi kehidupan manusia.

c. Kediaman Bala Rodra

Sebuah tempat tinggal yang terdapat pendapa dan memiliki halaman yang luas. Kediaman Bala Rodra terletak di desa Sembulung. Desa Sembulung letaknya berada dipelosok dan sangat jauh dari istana kadipaten Brang Wetan. Penciptaan latar tempat kediaman Bala Rodra digunakan sebagai tempat terjadinya persekongkolan Bala Rodra dengan Ki Ageng Candhala.

Pada naskah drama Bhre Satya Palastra latar waktu terjadinya peristiwa masa kerajaan. Ketika terciptanya hukum berdasar pada keputusan seorang raja. Sehingga benar dan salah tergantung pada kebijaksanaan seorang raja. Latar waktu pada naskah drama Bhre Satya Palastra hanya akan menjelaskan bahwa peristiwa yang terjadi dalam naskah merupakan masa pemerintahan Ratu Ayu Lembayung pada kerajaan Brang Kulon dan masa pemerintahan Bhre Satya di kadipaten Brang Wetan.

Suasana dimulai dengan kerumitan mimpi yang menghantui Bhre Satya. 
Kemudian berubah menjadi tegang karena pertempuran. Latar suasana pada naskah ini menjadi semakin rumit ketika isu-isu tidak benar yang dituduhkan kepada Bhre Satya menyebabkan kebencian dan persekongkolan. Akibatnya suasana menjadi kacau tidak terkendali. Kemudian suasana menjadi cair dengan percintaan yang berujung pada ketragisan karena terbunuhnya Bhre Satya. Suasana beranjak kembali pada ketegangan perjuangan Widura mencari kebenaran yang berbuah kemenangan. Pada akhir cerita, latar suasana menjadi mengantung karena Widura pergi setelah menolak titah Ratu Ayu Lembayung dan hal tersebut membuat Ratu Ayu Lembayung menjadi bingung untuk memberi keputusan pada nasib Ki Ageng Candhala, Candra Laleyan dan Bala Rodra. Namun cerita diakhiri dengan terbuka.

\section{Penciptaan Tokoh}

\section{Bhre Satya}

Seorang adipati yang masih muda, tampan, gagah, dan bijaksana. Namun karena kebaikan hatinya, membuat $\mathrm{Ki}$ Ageng Candhala iri padanya yang menyebabkan dirinya difitnah melakukan pemberontakan. Tokoh Bhre Satya mewakili sosok pemimpin yang jujur dan setia namun menjadi kambing hitam dari pemimpin yang melakukan penyimpangan. Bhre Satya memiliki ilmu kanuragan yang sangat sakti. Kelemahan Bhre Satya terletak pada pusakanya, yaitu Gada Wesi Kuning. Sehingga ia mudah dikalahkan oleh Candra Laleyan.

Tokoh Bhre Satya menjadi tokoh sentral dalam naskah drama Bhre Satya Palastra karena pada keseluruhan cerita Bhre Satya menjadi pusatnya. Bhre Satya merupakan tokoh protagonis yang menjadi peran utama atau merupakan pusat/sentral cerita. Berdasarkan pada sifat dan karakter Bhre Satya yang tidak pernah berubah atau statis, maka tokoh Bhre Satya termasuk ke dalam tokoh datar atau pipih.

2. Widura

Seorang abdi yang setia dan sakti. Ia sudah tidak muda lagi tapi juga belum terlalu tua. Memiliki sifat jenaka, gigih, sabar dan bijaksana. Namun ketika sedang marah ia menjadi sosok yang menakutkan. Tokoh Widura menggambarkan seseorang yang tidak setuju pada tindakan menyimpang penguasa. Bahkan Widura berusaha untuk mengungkap kebenaran yang ada.

Widura menjadi tokoh andalan yang menjadi kepercayaan protagonis. Meski tidak menjadi tokoh utama, namun Widura menjadi tokoh yang membawa penyelesaian konflik. Tokoh Widura memberi gambaran lebih terperinci tentang protagonis. Dilihat dari perkembangan perwatakannya, Widura merupakan tokoh datar karena tidak terjadi pengembangan perwatakan.

3. Ki Ageng Candhala

Seorang lelaki tua yang dianggap bijaksana oleh rakyat Brang Kulon, berkedudukan sebagai mahapatih Brang Kulon, licik, kejam dan haus kekuasaan.

$\mathrm{Ki}$ Ageng Candhala digunakan untuk mencerminkan sosok pemimpin yang selalu haus akan kekuasaan dan harta. Sehingga ia melakukan

segala cara untuk memenuhi hasrat tersebut. Berdasarkan pada kejiwaannya tersebut, $\mathrm{Ki}$ Ageng Candhala menjadi tokoh antagonis dalam naskah drama Bhre Satya Palastra. Ki Ageng Candhala menghasut semua orang untuk membenci Bhre Satya. Dengan cara menyebarkan isu bahwa Bhre Satya hendak melakukan pemberontakan pada Brang Kulon. Namun Ki Ageng Candhala melakukannya dengan halus, sehingga bagi rakyat Brang Kulon ia merupakan sosok patih yang bijaksana. Jika dilihat dari perubahan sifatnya, maka $\mathrm{Ki}$ Ageng Candhala merupakan tokoh bulat 
yang mengejutkan melalui perubahan sifatnya.

4. Candra Laleyan

Pemuda tampan yang berasal dari desa ini mengabdikan dirinya di kerajaan Brang Kulon sebagai seorang pengurus kuda. Candra Laleyan juga memiliki sifat yang licik, mudah terhasut, dan mudah menyesal. Tokoh Candra Laleyan menggambarkan sosok yang tidak tahu sebab akibat dari suatu pertikaian atau konflik, namun karena terhasut ia menjadi sangat bergejolak. Tokoh Candra Laleyan ini mewakili masyarakat luas yang mudah terhasut dengan isu yang sedang berkembang meski mereka tidak mengetahui kebenaran peristiwa yang terjadi. Dengan ketidaktahuan tersebut mereka menjadi sosok yang mengerikan dan brutal. Akibatnya pada naskah drama Bhre Satya Palastra ini Candra Laleyan membunuh Bhre Satya. Candra Laleyan juga termasuk kedalam tokoh bulat karena perubahan wataknya yang mengejutkan dan tidak terduga-duga.

5. Bala Rodra

Patih Brang Wetan yang kuat, sakti, gagah dan perkasa. Memiliki sifat yang kasar. Namun merupakan sosok yang sangat peduli pada keadilan dan memiliki rasa empati yang tinggi. Penciptaan tokoh Bala Rodra digunakan untuk menggambarkan pihak yang sebenarnya memiliki loyalitas namun karena sesuatu hal menjadi berkhianat.

Pada naskah drama Bhre Satya Palastra dapat dilihat melalui peristiwa Bala Rodra yang berkhianat pada Bhre Satya karena bersekongkol dengan $\mathrm{Ki}$ Ageng Candhala. Terlebih Ki Ageng Candhala menjanjikan posisi sebagai adipati Brang Wetan ketika Bhre Satya berhasil dimusnahkan.

6. Ratu Ayu Lembayung

Seorang ratu dari kerajaan Brang Kulon yang cantik dan mempesona.
Namun, Ratu Ayu Lembayung mudah untuk dihasut. Pendiriannya mudah sekali digoyahkan. Meskipun begitu, sebagai seorang ratu ia tetap memiliki wibawa tapi kurang bijaksana dan kurang tegas. Penciptaan tokoh ini untuk mewakili seorang pemimpin yang sebenarnya baik namun kurang tegas, mudah dihasut dan kurang bijaksana.

7. Parusya

Putri raja Klungkung yang cantik, kasar dan pemarah. Parusya digambarkan sebagai seorang putri raja yang penuh dengan ambisi. Ia ingin menjadi permaisuri satu-satunya di kadipaten Brang Wetan. Karena ambisinya tersebut, Parusya hampir tergoda pada Candra Laleyan yang berparas tampan dan menjanjikan Parusya menjadi permaisuri nantinya. Namun, Parusya tidak pernah berselingkuh dan membeberkan kelemahan Bhre Satya. Parusya mewakili penggambaran sosok wanita yang secara penampilan dianggap buruk namun nyatanya ia tidak sepenuhnya buruk. Tokoh Parusya merupakan tokoh bulat karena mengungkap watak yang tidak terduga.

8. Komala

Putri raja Klungkung yang cantik, lemah lembut, baik hati dan ramah. Komala tidak memiliki ambisi apapun. Ketika Komala bertemu dengan Candra Laleyan hatinya langsung berdegup dan menjadi kasmaran. Komala kemudian berselingkuh dengan Candra Laleyan. Supaya dapat hidup bersama dengan Candra Laleyan, Komala memberitahukan kelemahan Bhre Satya. Hal tersebut yang mengakibatkan Bhre Satya dapat dibunuh oleh Candra Laleyan. Tokoh Komala menggambarkan sosok istri yang tidak setia. Komala merupakan tokoh bulat karena sifatnya mengalami perubahan dan menghadirkan kejutan.

9. Pawitra

Putri Ki Ageng Candhala yang cantik, mungil dan lemah lembut. Pawitra 
tidak memiliki ambisi menguasai seperti ayahnya. Ia sangat mencintai Candra Laleyan dan ingin menikah dengan Candra Laleyan. Hasrat ini membuat Pawitra memaksa Candra Laleyan untuk turut serta melakukan penyerangan pada Bhre Satya. Pawitra digunakan sebagai senjata oleh $\mathrm{Ki}$ Ageng Candhala untuk menghasut Candra Laleyan. Akan tetapi Pawitra tidak mengetahui hal tersebut.

\section{Penciptaan Konflik}

Naskah drama Bhre Satya Palastra menggunakan konflik antar manusia dan juga konflik batin. Secara keseluruhan konflik yang terjadi akibat dari nafsu alamiah manusia untuk selalu menang dan menjadi penguasa. Contoh konflik antar manusia yang akan dipergunakan pada naskah drama Bhre Satya Palastra adalah ketika isu bahwa Bhre Satya memberontak mulai menyebar. Meskipun tidak secara langsung dihadirkan, namun konflik ini menjadi penyebab dari konflik-konflik yang terjadi selanjutnya. Bhre Satya dihantui hingga menjadi mimpi buruk. Kerusuhan terjadi di seluruh wilayah kadipaten Brang Wetan. Sedangkan contoh kejadian yang menggunakan konflik batin pada naskah drama Bhre Satya Palastra terdapat pada bagian ketika Bhre Satya terdiam memikirkan kerusuhan yang terjadi di kadipaten Brang Wetan. Bhre Satya merasa bersalah dan takut apa yang ia lakukan merugikan orang lain. Sebagai seorang adipati, Bhre Satya sampai tidak nyenyak tidur karena memikirkan cara mengatasi kerusuhan yang terjadi di kadipaten Brang Wetan.

Pada prolog diawali dengan konflik pertempuran yang merupakan gambaran mimpi Bhre Satya. Mimpi tersebut telah datang berkali-kali. Mimpi Bhre Satya tentang pertempuran yang berakhir pada kemenangannya namun banyak orang yang menjadi korban menjadi wujud dari ketakutan yang selama ini dirasakan oleh Bhre Satya. Akibatnya banyak ketakutan Bhre satya untuk menyelesaikan kerusuhan yang terjadi di kadipaten Brang Wetan. Hal ini menjadi konflik yang sengaja diciptakan untuk menggambarkan kepedulian dan kecintaan Bhre Satya pada rakyatnya.

Konflik selanjutnya yang terjadi adalah perselingkuhan Candra Laleyan dengan Komala yang berakibat terbunuhnya Bhre Satya. Candra Laleyan yang terhasut oleh $\mathrm{Ki}$ Ageng Candhala kemudian menyamar sebagai prajurit kadipaten Brang Wetan. Dengan kekuatan mantra, Komala salah satu istri Bhre Satya menjadi jatuh hati pada Candra Laleyan. Perselingkuhan merekapun terjadi. Komala memberitahukan kelemahan Bhre Satya dan bekerja sama pula untuk mencurinya.

Kematian Bhre Satya memunculkan konflik baru yaitu kemarahan Widura. Sebagai sosok yang pandai dan bijaksana, kemarahan Widura tidak meledak-ledak seperti tokoh Parusya. Widura menjalankan siasat untuk mengetahui pembunuh Bhre satya dengan cara menyebarkan isu bahwa arwah Bhre Satya gentayangan dan menuntut balas pada pembunuhnya. Rupanya selain mengetahui pembunuh Bhre Satya, Widura juga menemukan kebenaran bahwa tuduhan pemberontakan Bhre Satya didalangi oleh Ki Ageng Candhala.

Konflik puncak terjadi di adegan akhir. Adegan ketika Widura melakukan kesaksian dihadapan Ratu Ayu Lembayung. Pada mulanya adegan ini hanyalah perang argumentasi antara Widura dengan Ratu Ayu Lembayung. Namun karena terpancing emosinya, Bala Rodra menjadi brutal dan bertarung dengan Widura. Pertarungan dimenangkan oleh Widura karena ia menggunakan keris milik Bhre Satya pemberian dari Ki Pamengger. Setelah pertarungan tersebut, Widura semakin berani menyatakan pendapatnya dan menunjukkan bukti-bukti. Ratu Ayu 
Lembayung semakin bingung menentukan keputusan. Akan tetapi karena terkesima kesetiaan Widura, Ratu Ayu Lembayung memutuskan untuk menobatkan Widura sebagai adipati Brang Wetan. Karena Ratu Ayu Lembayung menginginkan seseorang yang setia seperti Widura berada dibawah kuasanya. Namun Widura menolak titah tersebut dan memilih untuk kembali ke desa menjadi petani legen. Bagi Widura kekuasaan bukanlah tugasnya, tugasnya ialah mendampingi Bhre Satya. Tugasnya telah selesai ketika nama Bhre Satya bersih kembali.

\section{Simpulan}

Proses penciptaan naskah drama Bhre Satya Palastra merupakan sebuah proses yang panjang. Berangkat dari perbedaan versi tokoh Menak Jingga yang menimbulkan kontroversi dan salah satu versi tokoh Menak Jingga yang mengakibatkan stigma negatif bagi masyarakat Banyuwangi. Dengan kata lain, penciptaan naskah drama Bhre Satya Palastra terinspirasi dari perbedaan versi tokoh Menak Jingga pada cerita rakyat Damarwulan - Menak Jingga.

Penciptaan naskah drama ini bertujuan untuk mengambarkan kondisi sosial dan politik yang saat ini terjadi. Proses penciptaan dilakukan dengan meninjau kondisi sosial dan politik dengan interpretasi yang didukung oleh literatur. Dengan menjadikan kondisi sosial dan politik saat ini serta perbedaan versi tokoh Menak Jingga sebagai sumber penciptaan, penulis yakin dapat menjadi perpaduan yang baik. Karena kedua sumber penciptaan ini saling berhubungan satu sama lain. Pada cerita rakyat Damarwulan - Menak Jingga mencerminkan kondisi sosial dan politik pada masanya. Sedangkan kondisi sosial dan politik saat ini menjadi unsur kontekstualitas naskah drama Bhre Satya Palastra.
Proses penyaduran dengan teori resepsi dilakukan berdasarkan pada hasil analisis dengan diakronik. Penyaduran dilakukan pada isi cerita, alur, nama tokoh, karakter tokoh, latar tempat, latar waktu, latar suasana, tema, konflik dan dialog. Setelah itu barulah mulai menulis sinopsis, treatment, adegan, dan kemudian merangkainya menjadi sebuah naskah drama yang utuh.

Pada tahapan ini, naskah drama yang telah dirangkai mengalami perubahan karena revisi, mendapat inspirasi baru, dan gagasan-gagasan yang dirasa sesuai dengan naskah. Hal ini menjadikan proses penciptaan naskah Bhre Satya Palastra terbagi menjadi 7 draft. Sampai pada akhirnya draft ketujuh merupakan draft terakhir.

Setelah melalui proses penciptaan seperti yang disebutkan, maka terciptalah sebuah naskah drama dengan judul Bhre Satya Palastra yang mempunyai pesan utama bahwa kekuasaan, cinta, dan pengkhianatan menjadi bernilai sama, yaitu keburukan jika hanya untuk menuruti nafsu semata.

Menciptakan sebuah naskah drama adalah salah satu proses kreatif sebagai wujud dari interpretasi suatu ide atau gagasan. Proses penciptaan naskah ini tidak terlepas dari kesulitan dan kendala. Utamanya dalam mencari bahan-bahan yang digunakan untuk memperkuat sumber penciptaan. Terlebih ketika mengolah sumber penciptaan tersebut menjadi sebuah naskah drama dengan versi baru yang berbeda dari cerita rakyat Damarwulan Menak Jingga yang sudah ada sebelumnya. Sehingga alangkah baiknya, jika pada proses penciptaan naskah drama lebih fokus terlebih dahulu pada sumber penciptaan. Hal ini dilakukan agar tidak timbul kesulitan atau masalah ketika sampai pada tahapan penulisan naskah. 
Sebagai seorang penulis naskah sebaiknya memahami objek tulisannya atau sumber penciptaannya. Ide yang dipilih betul-betul lahir dari kegelisahan diri seorang penulis, sehingga tidak terkesan mengikuti pada sesuatu yang sedang marak. Karena pasti berakibat pada hasil akhir naskah yang diciptakan. Sehingga diperlukan proses analisis yang panjang untuk menunjang proses penciptaan. Menyaksikan segala macam hal yang berhubungan secara langsung dengan sumber penciptaan ataupun yang memiliki tujuan sama dengan naskah yang akan diciptakan bisa juga membantu dalam memunculkan ide baru.

\section{Daftar Pustaka}

Anoegrajekti, N. (2014). Janger Banyuwangi dan Menakjinggo: Revitalisasi Budaya. Literasi Jurnal Ilmu-ilmu Humaniora, 4 (1), 116127.

Dewojati, C. (2012). Drama Sejarah, Teori dan Penerapannya. Yogyakarta: Javakarsa Media.

Hariadi, L. K. (2013). Menak Jingga Sekar Kedaton. Surakarta: Tiga Seragkai.

Harymawan. (1986). Dramaturgi. Bandung: Remaja Rosdakarya.

Irawan, Y. (2013). Babad Majapahit Jilid II Menak Djingga Nglurug Majapahit. Jakarta: Perpustakaan Nasional Republik Indonesia.

Iswantara, N. (2016). Drama Teori dan Praktik Seni Peran. Yogyakarta: Media Kreativa.

Jabrohim. (2009). Cara Menulis Kreatif. Yogyakarta: Pustaka Pelajar.

Keraf, G. (2010). Argumentasi dan Narasi. Jakarta: Gramedia Pustaka Utama.

Kuardhani, H. (2000). Teater Rakyat Janger Banyuwangi Ungkapan Keberadaan Masyarakat Pendukungnya. (Unpublished thesis). Universitas
Gadjah Mada, Yogyakarta, Indonesia.

Nurullita, H. (2015). Stigmatisasi Terhadap Tiga Jenis Seni Pertunjukan Di Banyuwangi: Dari Kreativitas Budaya Ke Politik. Jurnal Kajian Seni, 2(1), 35-51.

Pane, S. (2013). Sandhyakala Ning Majapahit. Bandung: Pustaka Jaya.

Ratna, N. K. (2015). Teori, Metode, dan Teknik Penelitian Sastra dari Strukturalisme hingga

Postrukturalisme. Yogyakarta: Pustaka Pelajar.

Satoto, S. (1993). Kajian Drama $I$. Surakarta: STSI Press Surakarta.

Supadma. (2011). Langendriya dan Serat Darmawulan: Suatu Kajian Pendekatan Intertekstual. Mudra, 26(1), 25-35.

Teeuw, A. (2015). Sastra Dan Ilmu Sastra. Bandung: Pustaka Jaya. 